\title{
Corossitivity of Pollutants from Gas Flares on Galvanised Roofing Sheets in Idu, Rivers State, Niger Delta of Nigeria
}

\author{
Happy Wilson Abali ${ }^{1, *}$, Ongoebi M. Etebu' ${ }^{2}$, Tambari G. Leton ${ }^{1, *}$ \\ ${ }^{1}$ Centre of Occupational Health, Safety \& Environment, University of Port Harcourt, Nigeria \\ ${ }^{2}$ Faculty of Engineering, University of Port Harcourt, Nigeria \\ *Corresponding author: hwabali@yahoo.com
}

\begin{abstract}
The rate of corrosion of roofing sheets especially those made of galvanized sheets is very high in the Niger Delta of region Nigeria. This could be due to the high level of atmospheric pollutants emitted mainly from gas and other industrial activities. To determine the impact of atmospheric pollutants, two shades were constructed at Idu, an oil bearing community with three gas flares. The shades were installed windward to provide maximum exposure to atmospheric pollutants and the rate of corrosion monitored nine-month period. The first shade was inclined at $30^{\circ}$ while the second was inclined at $70^{\circ}$. A sheet was removed from each of the shades monthly and comparison made with its original characteristics and corrosion rate noted. The rate of corrosion is the speed at which any metal in a specific environment deteriorates. The corrosion of galvanized corrugated iron sheet is the deterioration of galvanized corrugated iron sheet as a result of air pollutant reactions. Pollutants act faster in dry season than rainy season when acid rain is diluted beyond $\mathrm{pH}$ of 5.3 which is more than its corrosion strength. Besides at the inclination of $70^{\circ}$ does not allow pollutants to settle on the roof and therefore corrosion is minimal.
\end{abstract}

Keywords: air pollutants, atmospheric corrosion, roofing sheets corrosion

Cite This Article: Happy Wilson Abali, Ongoebi M. Etebu, and Tambari G. Leton, "Corossitivity of Pollutants from Gas Flares on Galvanised Roofing Sheets in Idu, Rivers State, Niger Delta of Nigeria." Journal of Environment Pollution and Human Health, vol. 6, no. 1 (2018): 1-6. doi: 10.12691/jephh-6-1-1.

\section{Introduction}

The menace of conventional gas flaring, indiscriminate and unchecked burning of bushes and hydrocarbons have made particulate pollution reach an alarming level in the Niger Delta of Nigeria. The change in the level of particulate matter pollution is affected by various sources of emission mainly industrial emission from convectional gas flaring. Other sources are power plants, vehicles and biogenic sources like indiscriminate burning of hydrocarbons and windblown dust. The change in atmospheric concentration of any pollutant is however affected by source strength or emission rate and meteorological factors such as rain, sunlight, geography, cloud cover, moisture, and weather patterns.

Air pollution is a concern to many people as it directly influences the quality of human health, especially respiratory problems, heart and lung diseases, and may in extreme cases cause death. Children are at greater risk as they are generally more active outdoors and their lungs are still developing, while elderly people are also sensitive to some serious types of air pollution [1].

Flare gas refers to the gases that are disposed of and flared into the atmosphere. Flare gas could contain sulfide and different contaminants like $\mathrm{H}_{2} \mathrm{~S}$ and sulfur dioxide and must therefore be treated before being released. However luckily, Nigerian crude has less than 5\% sulfur and sulfur treatment is unnecessary. Since flare gas emissions are often toxic or corrosive, they can contribute to the formation of acid rain especially because of its $\mathrm{NO}_{2}$ dioxide content. $\mathrm{NO}_{2}$ is an acid rain precursor as it reacts with moisture to form corrosive nitric acid. Acid rain is rainfall made so acidic by atmospheric pollution that it causes environmental harm, mostly to vegetation and stationary water bodies. The main cause in the Niger Delta of Nigeria is burning of fossil fuels, the waste gases which contain nitrogen oxides combine with atmospheric water to form acids.

$$
2 \mathrm{NO}_{2}+\mathrm{H}_{2} \mathrm{O}=2 \mathrm{HNO}_{3}-\cdots-- \text { acid rain }
$$

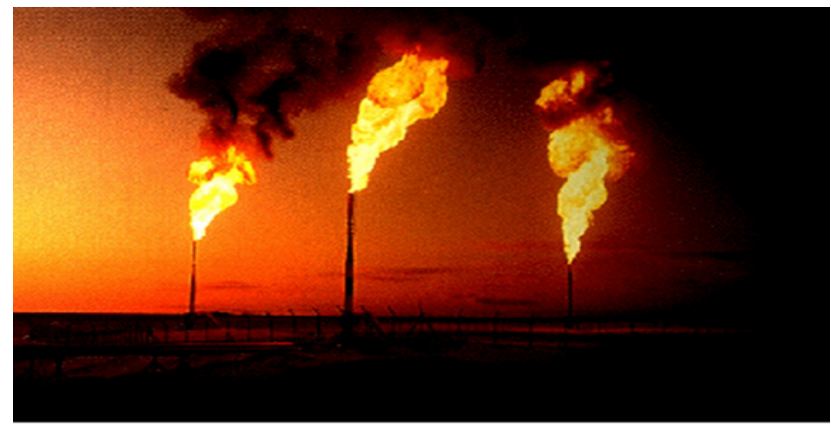

Figure 1. Major particulate matter pollution in Idu Ogba/Egbema/Ndoni Rivers State, Nigeria 
Table 1. Critical pollutants in Niger Delta of Nigeria

\begin{tabular}{|c|c|c|c|}
\hline Pollutants & Description & Sources & Effect \\
\hline Particulate Matter & $\mathrm{PM}_{2.5}$ and $\mathrm{PM}_{10}$ & $\begin{array}{l}\text { Residues from burning of } \\
\text { hydrocarbons - gas flaring etc }\end{array}$ & $\begin{array}{l}\text { increase respiratory symptoms, aggravate } \\
\text { asthma, and cause premature death. }\end{array}$ \\
\hline Carbon Monoxide (CO) & Poisonous gas & $\begin{array}{l}\text { incomplete combustion from vehicles } \\
\text { and gas flaring. }\end{array}$ & $\begin{array}{l}\text { affect mental function, alertness, and worsen } \\
\text { cardiovascular diseases. Harmful even in low } \\
\text { concentrations. }\end{array}$ \\
\hline Nitrogen Dioxide $\left(\mathrm{NO}_{2}\right)$ & $\begin{array}{l}\text { Reactive gas. Part of smog } \\
\text { formation }\end{array}$ & Vehicles and power plants, gas flaring & $\begin{array}{l}\text { Respiratory illness (short term). Lowers } \\
\text { resistance to respiratory infection (long term). }\end{array}$ \\
\hline Ozone $\left(\mathrm{O}_{3}\right)$ & $\begin{array}{l}\text { Reactive gas. Main chemical in } \\
\text { smog formation }\end{array}$ & $\begin{array}{l}\text { Sunlight reacting with exhaust from } \\
\text { motor vehicles and refineries }\end{array}$ & $\begin{array}{l}\text { significantly decrease lung function, increase } \\
\text { respiratory symptoms, aggravate asthma }\end{array}$ \\
\hline
\end{tabular}

Pollution studies carried out in the Niger Delta in the last five years, found these to be the critical air pollutants sulfur dioxide $\left(\mathrm{SO}_{2}\right)$, nitrogen oxide $\left(\mathrm{NO}_{2}\right)$, carbon monoxide $(\mathrm{CO})$, ground level ozone $\left(\mathrm{O}_{3}\right)$, lead $(\mathrm{Pb})$, fine particles less than 10 micrometers $\left(\mathrm{PM}_{10}\right)$ and nitric acid $\left(\mathrm{HNO}_{3}\right)[2,3]$.

\section{Materials and Methods}

Monitoring the corrosivity of pollutants on galvanized roofing sheets require a sequence of activities as described herewith. Two shades of galvanized roofing sheets $0.5 \mathrm{~mm}$ thick were constructed windward in January 2017. This study was carried out for nine months. Four months of dry season being from January to April and five months of rainy season May to September were covered in the study. While Shade A was roofed at inclination angle of $30^{\circ}$ which represents the angle of most of the buildings in Idu, Shade B was roofed at $75^{\circ}$. Weights of the sheets were taken before construction. At the end of each of the nine months of monitoring, a sheet was removed each from Shade A and Shade B, inspected and reweighed. The following Table 2 shows the rate of corrosion and progressive weight loss throughout the period of study.

Table 2. Co-ordinates of flaring site and pollutant monitoring locations

\begin{tabular}{|c|c|c|c|}
\hline \multirow{2}{*}{ S/N } & \multirow{2}{*}{ Location } & \multicolumn{2}{|c|}{ Co-ordinates } \\
\cline { 3 - 4 } & & NORTHING & EASTING \\
\hline 1 & Idu flow station & $5^{\circ} 14^{\prime} 33.00{ }^{\prime} \mathrm{N}$ & $6^{\circ} 36^{\prime} 5.22^{\prime \prime} \mathrm{E}$ \\
\hline 2 & Idu Obosi Ukwu & $5^{\circ} 14^{\prime} 44.35^{\prime} \mathrm{N}$ & $6^{\circ} 15^{\prime} 00.11^{\prime \prime} \mathrm{E}$ \\
\hline 3 & Idu Osobile & $5^{\circ} 14^{\prime} 12.13{ }^{\prime \prime} \mathrm{N}$ & $6^{\circ} 35^{\prime} 13.12^{\prime \prime} \mathrm{E}$ \\
\hline 4 & Obagi & $5^{\circ} 14^{\prime} 44.50^{\prime \prime} \mathrm{N}$ & $6^{\circ} 36^{\prime} 31.56^{\prime \prime} \mathrm{E}$ \\
\hline 5 & Oboburu & $5^{\circ} 13^{\prime} 49.63{ }^{\prime} \mathrm{N}$ & $6^{\circ} 36^{\prime} 06.62^{\prime \prime} \mathrm{E}$ \\
\hline
\end{tabular}

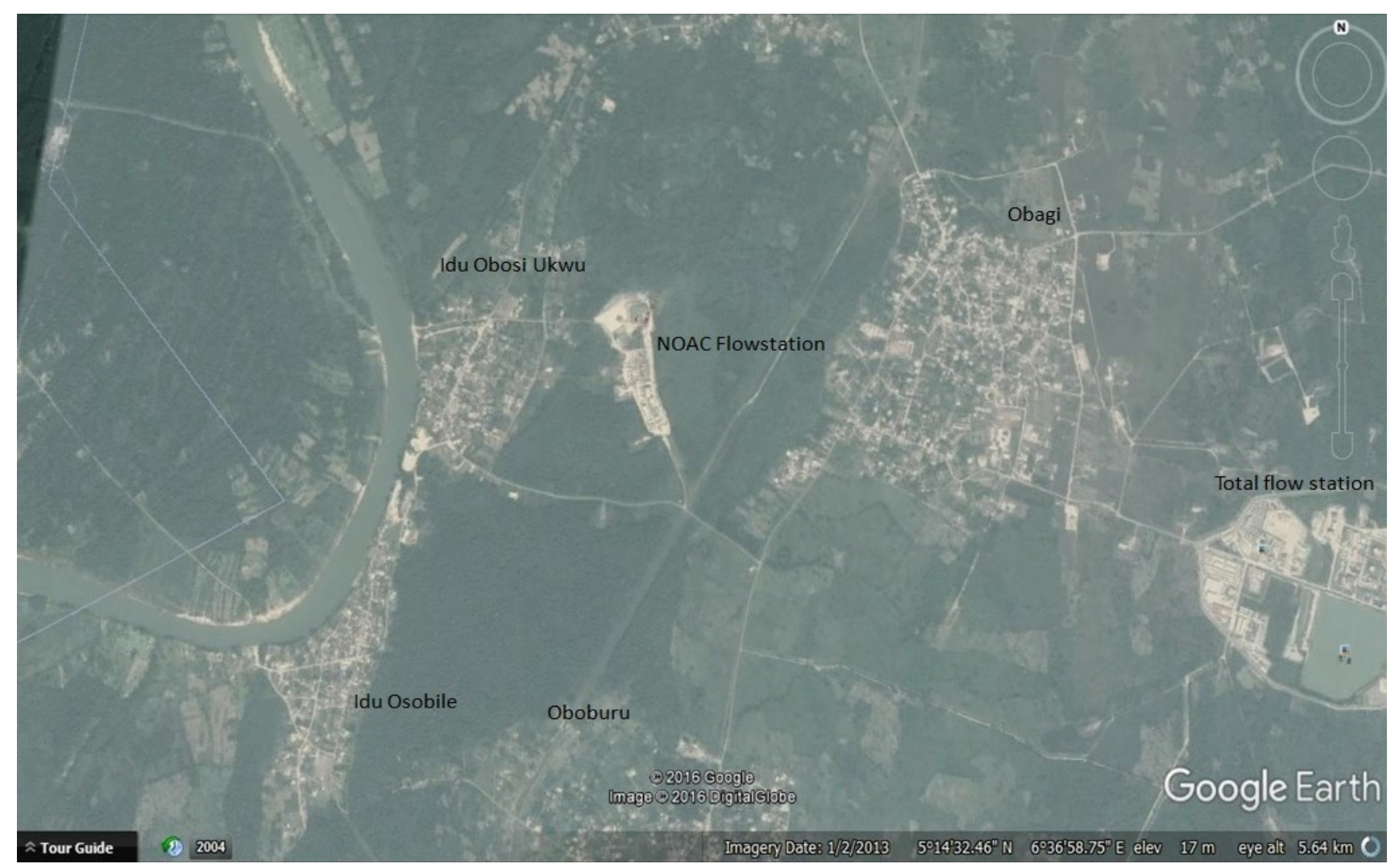

Plate 1. Satelite location of Idu and environs 
Table 3. Data obtained from Shade A $\left(3^{\circ}\right)$

\begin{tabular}{|c|c|c|c|c|c|c|c|}
\hline Month & $\begin{array}{c}\text { Average Ambient } \\
\text { Monthly Temp }{ }^{\circ} \mathrm{C}\end{array}$ & $\begin{array}{c}\text { Average Monthly } \\
\text { Humidity } \%\end{array}$ & $\begin{array}{c}\text { Initial weight } \\
(\mathrm{g})\end{array}$ & $\begin{array}{c}\text { After } \mathrm{x} \\
\text { days }\end{array}$ & $\begin{array}{c}\text { New weight } \\
(\mathrm{g})\end{array}$ & $\begin{array}{c}\text { Weight loss } \\
(\mathrm{g})\end{array}$ & $\begin{array}{c}\text { Progressive weight } \\
\text { loss }\end{array}$ \\
\hline Jan & 30.3 & 75 & 2190 & 30 & 2189.992 & 0.008 & 0.008 \\
\hline Feb & 29.9 & 78 & 2223 & 60 & 2222.981 & 0.019 & 0.011 \\
\hline Mar & 29.8 & 88 & 2075 & 90 & 2074.966 & 0.034 & 0.015 \\
\hline April & 28.9 & 89 & 2138 & 120 & 2137.947 & 0.053 & 0.019 \\
\hline May & 28.3 & 90 & 2253 & 150 & 2252.924 & 0.076 & 0.026 \\
\hline June & 27.3 & 91 & 2149 & 180 & 2148.89 & 0.110 & 0.035 \\
\hline July & 26.7 & 94 & 2219 & 210 & 2218.851 & 0.149 & 0.030 \\
\hline Aug & 27.2 & 95 & 2117 & 240 & 2116.832 & 0.168 & 0.019 \\
\hline Sept & 27.0 & 96 & 2236 & 270 & 2235.827 & 0.173 & 0.005 \\
\hline
\end{tabular}

Table 4. Data obtained from Shade B $\left(7^{\circ}\right)$

\begin{tabular}{|c|c|c|c|c|c|c|c|}
\hline Month & $\begin{array}{c}\text { Average Monthly } \\
\text { Temp }{ }^{\circ} \mathrm{C}\end{array}$ & $\begin{array}{c}\text { Average Monthly } \\
\text { Humidity\% }\end{array}$ & $\begin{array}{c}\text { Initial weight } \\
(\mathrm{g})\end{array}$ & After x days & $\begin{array}{c}\text { New weight } \\
(\mathrm{g})\end{array}$ & $\begin{array}{c}\text { Weight loss } \\
(\mathrm{g})\end{array}$ & $\begin{array}{c}\text { Progressive } \\
\text { weight loss }\end{array}$ \\
\hline Jan & 30.3 & 75 & 2280 & 30 & 2279.993 & 0.007 & 0.005 \\
\hline Feb & 29.9 & 78 & 2318 & 60 & 2317.99 & 0.010 & 0.003 \\
\hline Mar & 29.8 & 88 & 2278 & 90 & 2277.984 & 0.016 & 0.006 \\
\hline April & 28.9 & 89 & 2380 & 120 & 2379.979 & 0.021 & 0.005 \\
\hline May & 28.3 & 90 & 2240 & 150 & 2239.974 & 0.026 & 0.005 \\
\hline June & 27.3 & 91 & 2190 & 180 & 2189.968 & 0.032 & 0.006 \\
\hline July & 26.7 & 94 & 2220 & 210 & 2219.962 & 0.038 & 0.006 \\
\hline Aug & 27.2 & 95 & 2180 & 240 & 2179.957 & 0.043 & 0.004 \\
\hline Sept & 27.0 & 96 & 2260 & 270 & 2235.827 & 0.045 & 0.002 \\
\hline
\end{tabular}

\subsection{Rate of Corrosion}

Rate of Corrosion is the speed at which any metal in a specific environment deteriorates. It is also the amount of corrosion loss per year in quality and value of the material specimen. The speed or rate of deterioration depends on the environmental conditions and the type and condition of the metal under reference.
The rate can be expressed mathematically as follows: $\mathrm{R}=\mathrm{KW} /(\beta \mathrm{AT})$

Where $\mathrm{K}=$ constant

$\mathrm{W}=$ total weight loss

$\mathrm{T}=$ time taken for the loss to occur

$\mathrm{A}=$ the surface area of the exposed metal

$\beta=$ the metal density in $\mathrm{g} / \mathrm{cm}^{3}$

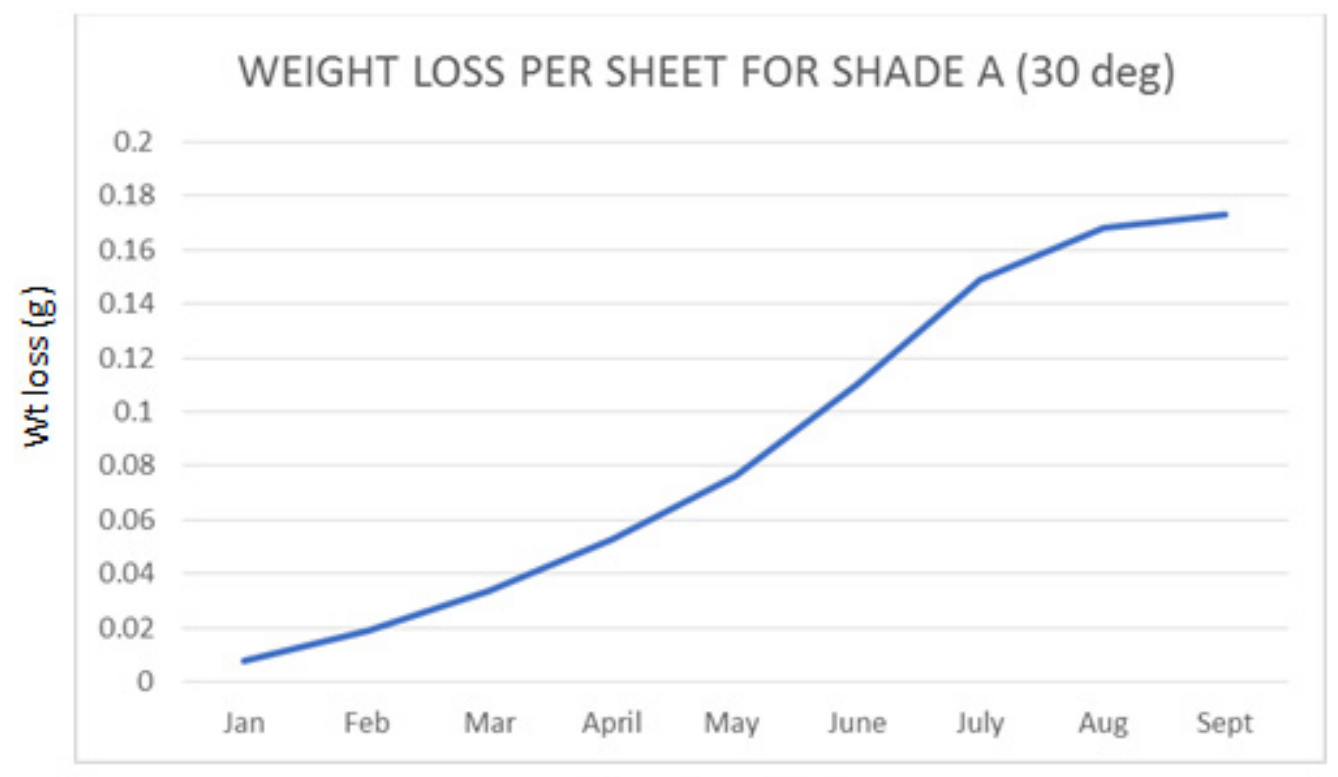

Time (months)

Figure 2. Weight loss per sheet for Shade A 


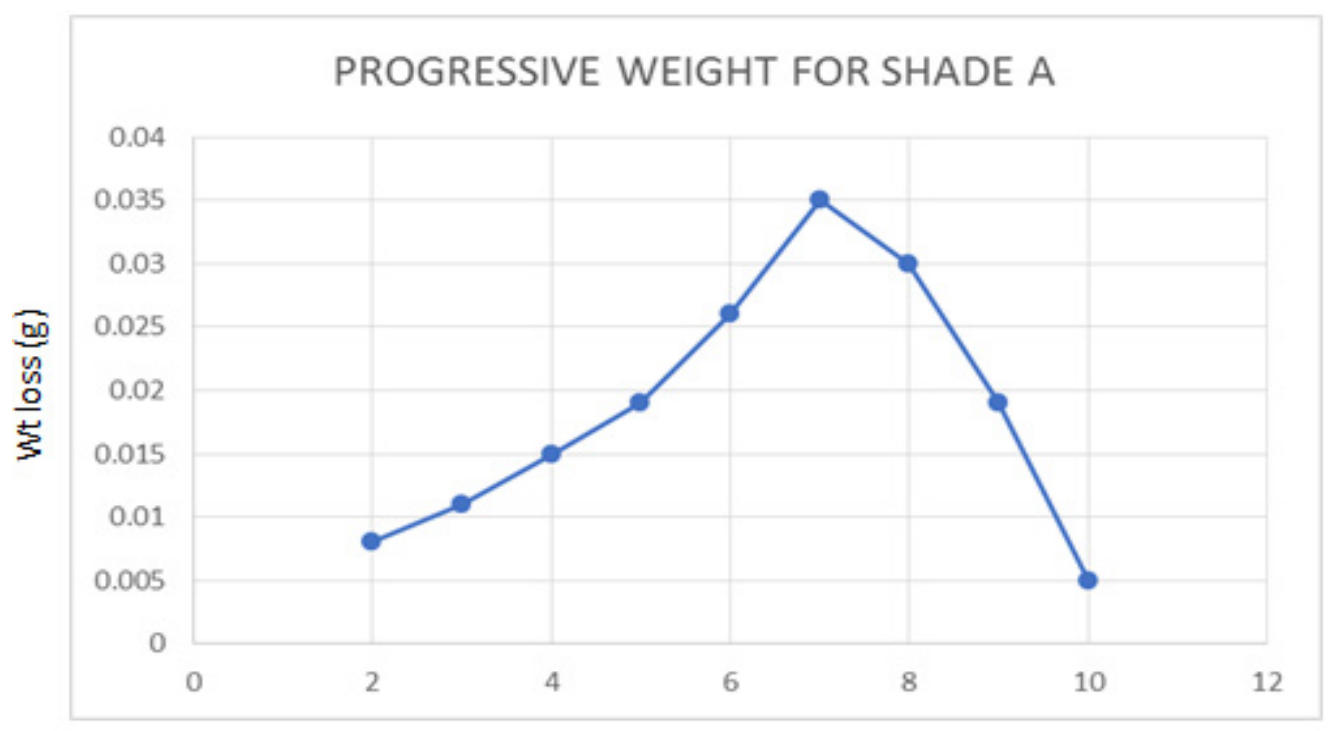

Time

Figure 3. Progressive weight loss for Shade A

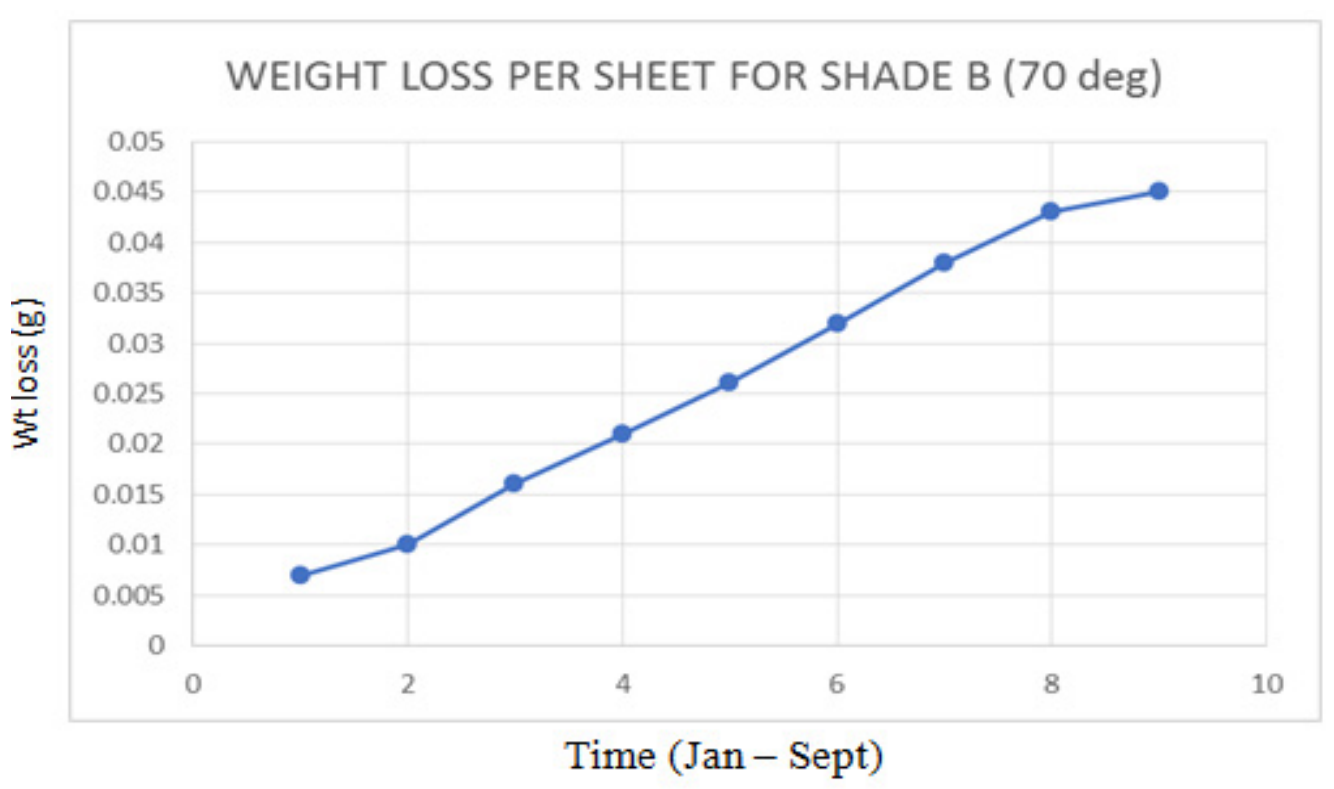

Figure 4. Weight loss per sheet for Shade B

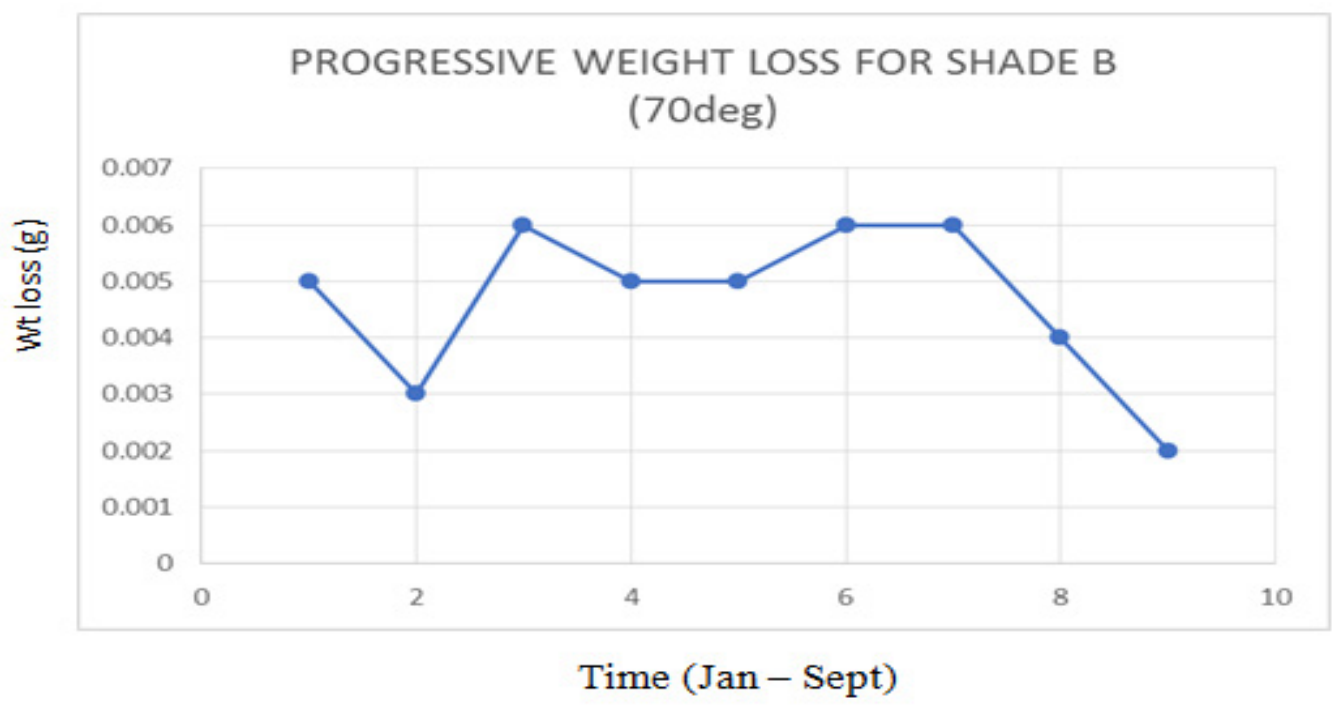

Figure 5. Progressive weight loss for $70^{\circ}$ inclined roof 


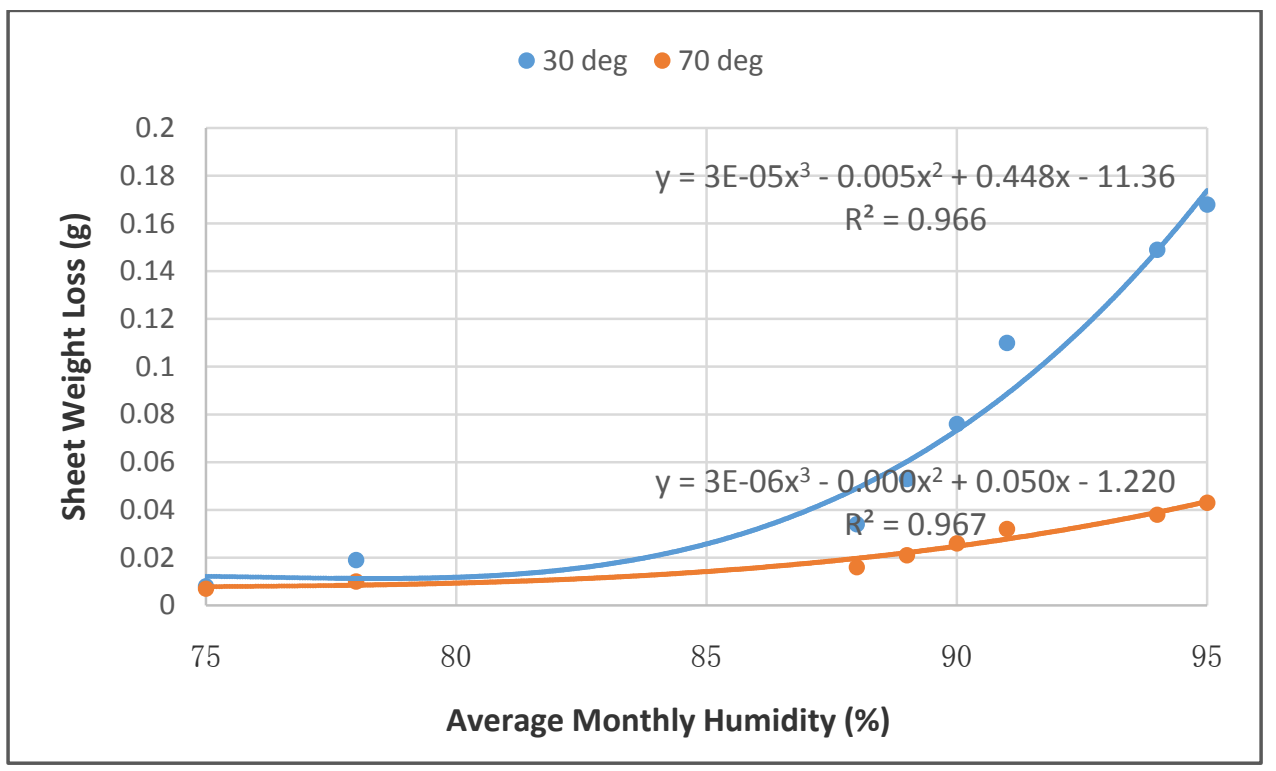

Figure 6. Humidity effect on weight loss for Shades A and B

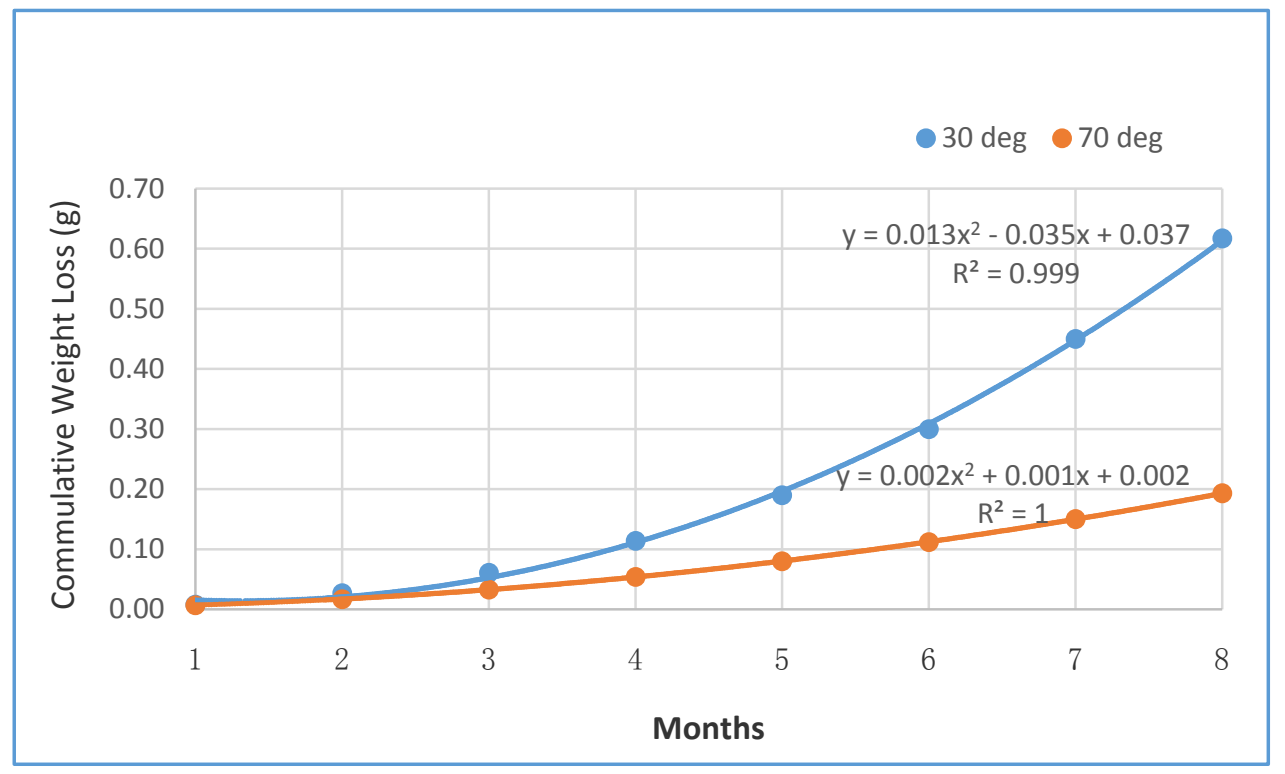

Figure 7. Monthly Cumulative Weight Loss for Shades A and B

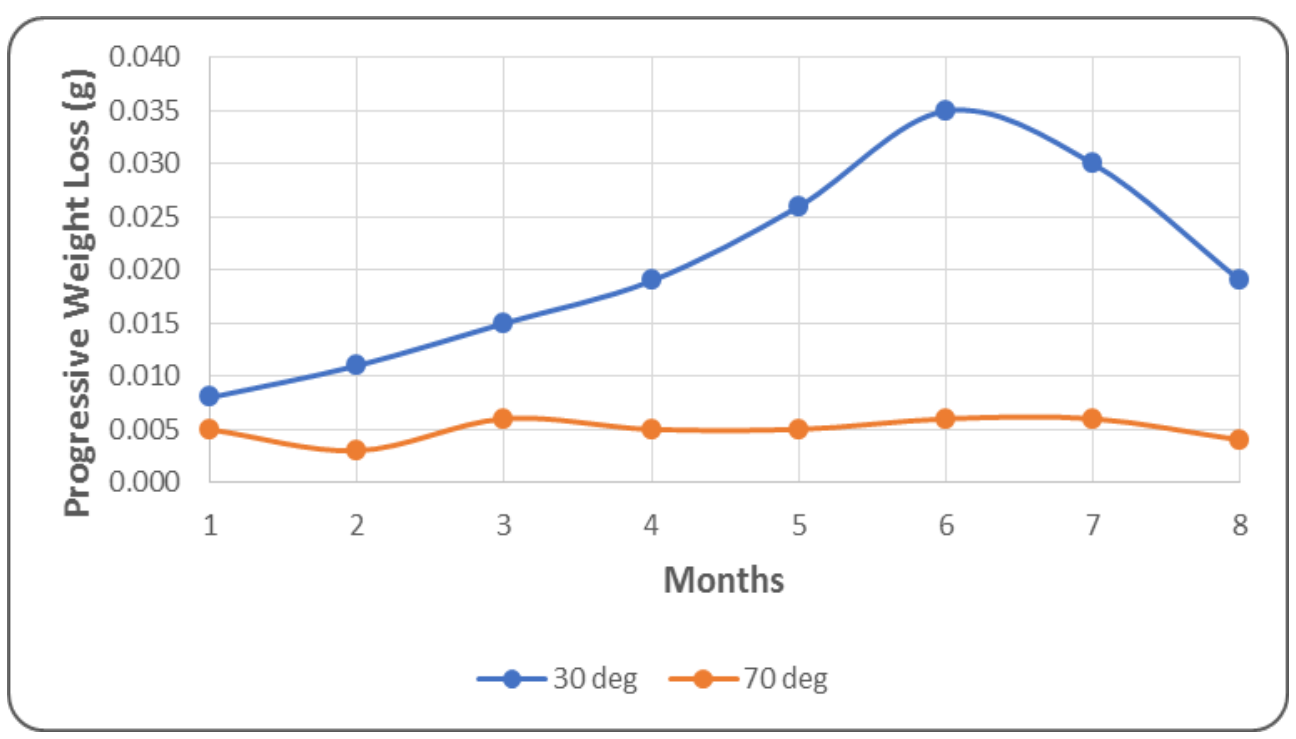

Figure 8. Monthly Progressive Weight Loss 
After June when the rains have fully come, the progressive weight loss started to decline.

The reason for this decline is the continual increase in rainfall that diluted nitric acid to more than $\mathrm{pH} 5.3$ which is beyond its corrosivity. The progressive weight loss continues to decline for the rest of the study period.

Weight loss per sheet was steadily on the increase throughout the study period.

However, the progressive weight loss as shown in Figure 5 was low to $0.003 \mathrm{~g}$ in February from 0.005 in January because of the occasional rainfall observed in February. This value wet up again for the dry month of March to about $0.006 \mathrm{~g}$. It was more or less steady during the months of April and May at $0.005 \mathrm{~g}$ before increasing to a steady level of $0.006 \mathrm{~g}$ during the months of June and July and plunged down to $0.004 \mathrm{~g}$ in August and $0.002 \mathrm{~g}$ in September as the rains increased.

\section{Discussion of Result}

Mereological parameters monitored include Temperature at ground level, wind speed and humidity at ground level. Air pollutants monitored include $\mathrm{NO}_{2}, \mathrm{PM}_{2.5}, \mathrm{PM}_{10}$ and $\mathrm{CH}_{4}$. Average daily $\mathrm{pH}$ of the humidity was taken during the dry season on $5^{\text {th }}$ March 2017, when the rains started setting on May $19^{\text {th }} 2017$, June $27^{\text {th }} 2017$ and $3^{\text {rd }}$ Sept 2017. There was a steady increase of daily average $\mathrm{pH}$ from 3.9 in March, 4.2 in May, 4.8 in June and 5.3 in September. This $\mathrm{pH}$ record with the average monthly humidity average (75\% for January, $78 \%$ for February, $78 \%$ for March, $80 \%$ for April, $83 \%$ for May, $85 \%$ for June, $90 \%$ for July and $95 \%$ for September) and air pollutants which were all above permissible exposure limits could contribute to wet and dry acid deposition. Acid deposition on metals lead to corrosion as observed sheet weight loss.

It was discovered that pollutants action mainly that of Nitrogen Dioxide $\left(\mathrm{NO}_{2}\right)$ causing Nitric Acid $\left(\mathrm{HNO}_{3}\right)$ rain when reacted with moisture and particulates matter which forms nuclides when settled on roofs. Galvanized roofing sheet physically went from loss of gloss (loss of galvanization) within the first few months of study to actual rusting of the roofing sheets as Nitrogen Dioxide $\left(\mathrm{NO}_{2}\right)$ is reacted with atmospheric moisture to form corrosive nitric acid. Besides, by inclining the roof at $75^{\circ}$ Shade B, the rate of corrosion was reduced as nitric acid making contact only with small surface area and shorter time. During rainy season active pollutants are scrubbed from the air and further diluted to a near neutral state ( $\mathrm{pH}$ 6.5) so that their corrosive ability is reduced to minimum. House roofs in Idu and environs are inclined at between $25^{\circ}$ and $30^{\circ}$. With higher humidity as in the months of April, May, June and July corrosion rate continuously increased until the months of higher precipitation when dilution of nitric acid is prevalent.

\section{Conclusion}

"The expected lifespan of a metal roof is 30 to 45 years in Florida. The most common metal roof material we see in this area is galvalume, which is a steel sheet with an electrolytically-applied coating of a combination of zinc and aluminum to extend the lifespan" (www.mcgarryandmadsen.com/.../16 What is the avera ge lifespan of a metal \%2... Dec 16, 2014.) At an average roof life maximum of 15years (Idu residents 2017) these buildings with galvanized roof (coated with zinc) are reroofed because of pollutant caused corrosion which roofs in Florida USA quoted above are not exposed to. By inclining the roof at $70^{\circ}$ life of these buildings can achieve the expected life span above because the rate of corrosion is greatly reduced. Alternatively, stone coated roofing sheets can be employed as they are manufactured to withstand corrosion than ordinary galvanizing or zinc coating. Second alternative is galvalume or aluminum roofing sheets which corrodes slower than galvanized and the other non-aluminum roofing sheets.

\section{References}

[1] Abali, H.W; Environmental Monitoring And Modelling of Particulate Matter at Idu And Environs Rivers State of Nigeria. A dissertation work for $\mathrm{PhD}$ in Environmental Technology and Management of the Centre of Occupational Health, Safety and Environment, University of Port Harcourt. 2017. Unpubished

[2] Mishra V. Health Effects of Air Pollution. PopulationEnvironment Research Network (PERN) Cyberseminar. www.populationenvironmentresearch.org. 2003.

[3] Nwaogazie I. L; Abali H. W; and Henshaw T. Assessment of Standard Pollutants in a Gas Flaring Region: A Case of Ogba/Egbema/Ndoni Local Government Area in Rivers State of Nigeria. International Journal of Civil Engineering \& echnology (IJCIET). Volume: 7, Issue: 3, Pages: 7-17. 2016.

[4] Samia Fathy Hamed Esmail. Assessment of Concentration of Air Pollutants using Analytical and Numerical Solutions of The Atmospheric Diffusion Equation. A Thesis Submitted to Faculty of Science, Zagazig University for the Degree of Doctor of Philosophy in Mathematics. 2011.

[5] Abali, H. "Assessment of some pollutants from gas flaring in Ogba/Egbema/Ndoni Local Government Area of Rivers State", M.Sc Thesis work of the University of Port Harcourt, Nigeria. 2015.

[6] Anyanime, A. O. "Environmental Sustainability: Assessing the Impact of Air Pollutants Due to Gas Flaring - Qua Iboe Estuary Case" World Journal of Environmental Engineering Vol. 4, No. 1; pp 1-5. 2016

[7] Ite, Aniefiok E and Udoh J. Ibok. "Gas flaring and Venting Associated with Petroleum Exploration and Production in the Nigeria's Niger Delta" American Journal of Environmental Protection 1.4 (2013): 70-77.

[8] Pal Arya S. "Air Pollution, Meteorology And Dispersion" Oxford University Press, New York. 2000.

[9] Yang Li; Quanliang Chen; Hujia Zhao; Lin Wang and Ran Tao. 2015. "Variations in $\mathrm{PM}_{10}, \mathrm{PM}_{2.5}$ and $\mathrm{PM}_{1}$ in an Urban Area of the Sichuan Basin and their Relation to Meteorological factors" Atmosphere Journal 2015, 6, 150-163.

[10] Abril, G. A; Diez S. C.; Pignata M. L.; Britch J. "Particulate matter concentrations originating from industrial and urban sources: Validation of atmospheric dispersion modelling results" Elsever. Atmospheric Pollution Research Journal.2015.

[11] Querol X., A. Alastuey, S. Rodríguez, M. M. Viana, B. Artiñano, P. Salvador, E. Mantilla, S. García do Santos, R. Fernyez Patier, J.de la Rosa, A. Sanchez dela Campa and M.Menéndez. "Levels of PM in rural, urban and industrial sites in Spain" Sci. Tot. Environ. Pp 334-335, 359-376, 2004.

[12] Wahid, H; "Neural Network-based Metamodelling Approach for Estimation of Air Pollutant Profiles." A dissertation work for PhD submitted to Faculty of Engineering, University of Technology, Sydney, Australia. 2013. 